\title{
Evaluation of different culture media and enrichment in orange juice upon the growth of Alicyclobacillus spp.
}

\author{
Avaliação de diferentes meios de cultura e enriquecimento em suco de laranja \\ sobre o crescimento de Alicyclobacillus spp.
}

\author{
Márcia Maria Anjos ${ }^{1 *}$, Suelen Pereira Ruiz', Benício Alves Abreu Filho²
}

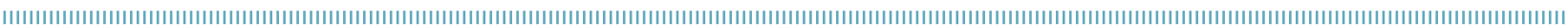

\begin{abstract}
Bacteria of the genus Alicyiclobacillus spp. form spores and develop in acid media, leading to the spoilage of citrus juices. Brazil is the largest exporter of orange juice concentrate, and yet, it has been extensively studied due to changes in taste and smell. Several investigations have reported different culture media used to detect and enumerate Alicyiclobacillus spp. The objective of the present study was to evaluate the recovery of Alicyiclobacillus spp. spores grown in ALI, BAT, $\mathrm{K}$ agar and YSG media using the methodology suggested by ABECitrus. Five inocula were used, two from reference strains and three from pasteurized concentrated orange juice. Cell recovery after the enrichment in reconstituted orange juice was also analyzed. An initial population of $6 \log \mathrm{CFU} / \mathrm{mL}$ was inoculated. ALI, BAT and YSG media were able to recover the initial population of all different inocula, with no significant differences between the results. When compared to BAT, however, the preparation of ALI and YSG media was simpler and had more advantages. The recovery with $\mathrm{K}$ agar medium was lower than the other media for all the tested inocula, with significant differences found for Alicyclobacillus acidocaldarius $0298^{\mathrm{T}}$ (3.66 log CFU/mL) and Alicyclobacillus pomorum-like CBMAI 0278 (4.11 log CFU/mL).
\end{abstract}

KEYWORDS: Alicyclobacillus; culture media; spores; orange juice.
RESUMO: As bactérias do gênero Alicyiclobacillus spp. formam esporos e se desenvolvem em meios ácidos, podendo causar deterioração em sucos cítricos. O Brasil é o maior exportador de suco de laranja concentrado do mundo e, assim, este gênero vem sendo estudado por causar alteraçôes de odor e sabor. Vários estudos relatam diferentes meios de culturas empregados para a detecçáo e enumeração de Alicyclobacillus spp. Este estudo teve como objetivo avaliar a recuperaçáo de esporos de Alicyclobacillus spp. nos meios ALI, BAT, K ágar e YSG, utilizando a metodologia indicada pela ABECitrus. Cinco inóculos diferentes foram utilizados, sendo dois de linhagens-referência e os outros três isolados de suco concentrado de laranja pasteurizado. Também foi verificada a recuperação das células após o enriquecimento em suco de laranja reconstituído. Foi inoculada uma populaçáo inicial de $6 \log \mathrm{UFC} / \mathrm{mL}$. Os meios ALI, BAT e YSG conseguiram recuperar esta população nos diferentes inóculos, não existindo diferenças significativas entre os resultados. Contudo, devido à facilidade do preparo, os meios ALI e YSG mostraram-se mais vantajosos quando comparados ao meio BAT. $\mathrm{O}$ meio $\mathrm{K}$ ágar apresentou recuperação inferior aos outros meios para todos os inóculos, porém, houve diferença significativa apenas para Alicyclobacillus acidocaldarius $0298^{\mathrm{T}}(3,66 \log \mathrm{UFC} / \mathrm{mL})$ e Alicyclobacillus pomorum-like CBMAI 0278 (4,11 log UFC/mL).

PALAVRAS-CHAVE: Alicyclobacillus; meios de cultura; esporos; suco de laranja.

\footnotetext{
'Programa de Pós-Graduação em Ciência de Alimentos; Universidade Estadual de Maringá (UEM) - Maringá (PR), Brazil. ${ }^{2}$ Departamento de Ciências Básicas da Saúde; UEM - Maringá (PR), Brazil.

*Corresponding author: marciamanjos@hotmail.com

Received on: 12/06/2012. Accepted on: 14/01/2014.
} 


\section{INTRODUCTION}

The genus Alicyclobacillus ssp. is comprised of bacteria which grow in acid media at high temperatures. They multiply in different types of food with $\mathrm{pH}$ lower than 3.7, such as tomatoes, citrus fruits, and their products (HipPeChen et al., 1981). Brazil is the largest exporter of orange juice concentrate in the world, accounting for 400,000 tons in 2011 (Citrus BR, 2012). As a result, several studies have been performed on new alternatives to prevent orange juice spoilage caused by bacteria such as the genus Alicyclobacillus spp.

Alicyclobacillus spp. are gram-positive, rod-like bacteria, whose cell membrane is mainly composed of cyclic fatty acids. They are spore-forming bacteria resistant to pasteurization processes employed in the production and reconstitution of concentrated orange juice. After pasteurization, spores may germinate and grow, therefore affecting the sensorial features of orange juice, such as smell and flavor and, occasionally, leading to the formation of sediments and turbidity (Silva; Gibbs, 2001). Some species of Alicyclobacillus, like A. acidoterrestris and A. acidocaldarius, may also exhale an anti-septic odor due to the formation of guaiacol (Gocmen et al., 2005).

Alicyclobacillus spp. are commonly present on the soil and may be detected by fine-tuned isolation and culture methodologies that are specific to their nutritional and mineral requirements (Мотоніro; Нiroко, 1994). As the thermal resistance of spores may be affected by media composition, ions, $\mathrm{pH}$ and organic acids, detection may be conducted in several different ways (Pontius et al., 1998).

Different species grow at different $\mathrm{pH}$ and temperature, thus making the development of a standard methodology highly difficult in order to assess the growth of Alicyclobacillus spp. Although several Agar culture media have been formulated in an attempt to detect specific species, they have only been able to detect species in general (Murray et al., 2007).

The objective of the present study was to evaluate the most commonly used culture media reported in literature (ALI, BAT, $\mathrm{K}$ agar and YSG), as well as the enrichment in orange juice upon the growth and recovery of three Alicyclobacillus species (A. acidoterrestris, $A$. acidocaldarius and $A$. pomorum-like) under the same temperature and $\mathrm{pH}$ conditions.

\section{MATERIALS AND METHODS}

\section{Microbial strains}

Standard strains of $A$. acidoterrestris and $A$. acidocaldarius supplied by the German Collection of Microorganisms and
Cell Cultures (Deutsche Sammlung von Mikroorganismen und Zellkulturen) were used. The isolates, kept at the Brazilian Collection of Environment and Industry Microorganisms (CBMAI) in the Multidisciplinary Center of Chemical, Biological and Agricultural Research (CPQBA/UNICAMP), Campinas, Brazil, were as follows:

- A. acidoterrestris DSM 3922 - (CBMAI: 0244 ${ }^{\mathrm{T}}$-O Origin: Soil

- A. acidocaldarius DSM 446 ${ }^{\mathrm{T}}$-(CBMAI: 0298 ${ }^{\mathrm{T}}$-OOrigin: Soil

Three species of Alicyclobacillus collected from orange juice concentrate plants were also used. The species were retrieved, identified and stored at CBMAI, as follows:

- A.acidoterrestris - CBMAI 0281

- A. acidocaldarius-CBMAI 0294

- A. pomorum-like - CBMAI 0278

Samples were kept at $-80^{\circ} \mathrm{C}$ at the Water, Environment and Food Microbiology Laboratory at Universidade Estadual de Maringá, Brazil.

\section{Orange juice concentrate}

Samples of orange juice concentrate were collected from a processing plant in the city of Paranavaí, Brazil. The absence of Alicyclobacillus was previously certified. The concentrate was produced on October 6, 2010, with $65.81^{\circ} \mathrm{Brix}$, and stored at $-18^{\circ} \mathrm{C}$ until analysis. The concentrate was later aseptically reconstituted to $12^{\circ} \mathrm{Brix}$ with sterile distilled water.

\section{Preparation of spores}

Standard suspensions containing spores of the reference strains and the orange juice isolates to be used as inoculants in the assays were prepared and kept refrigerated at $4^{\circ} \mathrm{C}$. Using a sowing loop, at least five isolate colonies were collected from a cell culture in BAT, and transferred to $3 \mathrm{~mL}$ tubes containing BAT broth; the suspension was incubated at $45^{\circ} \mathrm{C}$ for 24 hours. Later, $0.3 \mathrm{~mL}$ were resuspended in a sterile tube with $10 \mathrm{~mL}$ of BAT broth, being afterwards incubated at $45^{\circ} \mathrm{C}$ for 72 hours. The culture was then transferred to a cryotube and centrifuged at 10,000 rpm. The resulting precipitate was rinsed three times with sterilized distilled water and stored at $4^{\circ} \mathrm{C}$.

\section{Culture media composition}

The culture media used in the tests were prepared according to the procedures established in the different studies, and $\mathrm{pH}$ was standardized at 4.0 according to the components in their formulation, which are demonstrated in Table 1. 
Table 1. Culture media formulation.

\begin{tabular}{lcccc} 
Components & $\begin{array}{c}\text { BAT } \\
(\mathrm{g} / \mathrm{I})\end{array}$ & $\begin{array}{c}\mathrm{K} \text { agar } \\
(\mathrm{g} / \mathrm{I})\end{array}$ & $\begin{array}{c}\mathrm{YSG} \\
(\mathrm{g} / \mathrm{I})\end{array}$ & $\begin{array}{c}\mathrm{ALI} \\
(\mathrm{g} / \mathrm{I})\end{array}$ \\
\hline Soluble starch (Dinâmica) & - & - & 2 & 4 \\
\hline Yeast extract (Merck) & 2 & 2.5 & 2 & 4 \\
\hline Glucose (Nuclear) & 5 & 1 & 1 & 2 \\
\hline$\left(\mathrm{NH}_{4}\right)_{2} \mathrm{SO}_{4}$ (Nuclear) & 0.2 & - & - & 0.4 \\
\hline $\mathrm{Mg} \mathrm{SO}_{4} \cdot 7 \mathrm{H}_{2} \mathrm{O}$ (Synth) & 0.5 & - & - & 1 \\
\hline $\mathrm{CaCl}_{2} \cdot 2 \mathrm{H}_{2} \mathrm{O}$ (Nuclear) & 0.25 & - & - & 0.5 \\
\hline $\mathrm{KH}_{2} \mathrm{PO}_{4}$ (Merck) & 3 & - & - & 6 \\
\hline Peptone (Merck) & - & 5 & - & - \\
\hline Tween 8O (Sigma) & - & 1 & - & - \\
\hline Trace B* & 1 & - & - & - \\
\hline Agar (Difco) & 20 & 20 & 20 & 20 \\
\hline
\end{tabular}

Trace $B^{*}$ : solution of salts in trace elements (FARRAND et al., 1983).

\section{Preparation of Bacillus acidoterrestris thermophilic agar medium (DEINHARD et al., 1987)}

Bacillus acidoterrestris thermophilic agar (BAT) medium was prepared by weighing all of the components, except for agar, in $500 \mathrm{~mL}$ of distilled water. A solution of $1 \mathrm{~N} \mathrm{H}_{2} \mathrm{SO}_{4}$ or $1 \mathrm{~N}$ $\mathrm{NaOH}$ was used to adjust $\mathrm{pH}$ to 4.0. Agar was prepared separately in $500 \mathrm{~mL}$ of distilled water. After being autoclaved, the hot agar was added to the previously autoclaved medium components in a sterile environment. The resulting medium was immediately poured into the plates.

The formulation of trace $\mathrm{B}$ was established in $\mathrm{g} / \mathrm{L}$ of distilled water with $0.66 \mathrm{CaCl}_{2} \times 2 \mathrm{H}_{2} \mathrm{O} ; 0.18 \mathrm{ZnSO}_{4} \times 7 \mathrm{H}_{2} \mathrm{O}$; $0.16 \mathrm{CuSO}_{4} \times 5 \mathrm{H}_{2} \mathrm{O} ; 0.02 \mathrm{MnSO}_{4} \times 4 \mathrm{H}_{2} \mathrm{O} ; 0.18 \mathrm{CoCl}_{2} \mathrm{x}$ $6 \mathrm{H}_{2} \mathrm{O} ; 0.10 \mathrm{H}_{3} \mathrm{BO}_{3}$; and $0.3 \mathrm{Na}_{2} \mathrm{MoO}_{4} \times 2 \mathrm{H}_{2} \mathrm{O}$. The solution was sterilized by filtration after preparation.

\section{Preparation of $\mathrm{K}$ agar medium (WALls; Chuyate, 2000)}

Components of $\mathrm{K}$ agar medium were weighed in a single Erlenmeyer flask together with the agar. After being autoclaved, medium $\mathrm{pH}$ was adjusted to 4.0 in a sterile environment with an aqueous solution of $25 \%$ malic acid, sterilized by filtration and measured with a $\mathrm{pH}$ tape. The hot medium was immediately poured into the plates.

\section{Preparation of Yeast Starch Glucose agar medium (МотонIRO; НIROTо, 1994)}

Yeast Starch Glucose agar (YSG) medium was prepared by weighing all of the components in $500 \mathrm{~mL}$ of distilled water, except for agar; $\mathrm{pH}$ was then adjusted to 4.0 with a solution of $1 \mathrm{~N} \mathrm{H}_{2} \mathrm{SO}_{4}$ or $1 \mathrm{~N} \mathrm{NaOH}$. Agar was prepared separately in $500 \mathrm{~mL}$ of distilled water.

\section{Preparation of Alicyclobacillus agar medium (WISSE; PARISH, 1998)}

The preparation of Alicyclobacillus agar (ALI) medium was conducted by weighing all of the components in $500 \mathrm{~mL}$ of distilled water, except for agar; $\mathrm{pH}$ was then adjusted to 4.0 with a solution of $1 \mathrm{~N} \mathrm{H}_{2} \mathrm{SO}_{4}$ or $1 \mathrm{~N} \mathrm{NaOH}$. Agar was prepared separately in $500 \mathrm{~mL}$ of distilled water, autoclaved, mixed with the other components, and immediately poured into the plates.

\section{Enumeration of reference strains and orange juice isolates}

Standardized suspensions containing $6 \log \mathrm{CFU} / \mathrm{mL}$ of spores of the reference strains CBMAI $0244^{\mathrm{T}}$ and CBMAI $0298^{\mathrm{T}}$, as well as the orange juice isolates CBMAI 078, CBMAI 0281 and CBMAI 0294 were resuspended in sterile distilled water and underwent an $80^{\circ} \mathrm{C}$ thermal shock for 10 minutes. Additionally, $100 \mu \mathrm{L}$ were inoculated in duplicate on the four culture media by surface plating spread with a Drigalski loop. Plates were incubated at $45^{\circ} \mathrm{C}$ for five days, and results were monitored between three to five days. Colonies were fixed with Gram and spore staining (Wirtz-Conklin staining technique) to verify the morpho-staining characteristics under optical microscopy.

\section{Enumeration of Alicyclobacillus acidoterrestris with enrichment in reconstituted orange juice}

The suspension of CBMAI $0244^{\mathrm{T}}$ spores was diluted to $2 \log \mathrm{CFU} / \mathrm{mL}$, with the last dilution conducted in $9 \mathrm{~mL}$ of orange juice reconstituted with sterile distilled water at $12^{\circ} \mathrm{Brix}$. The juice containing the spores underwent an $80^{\circ} \mathrm{C}$ thermal shock for 10 minutes and was plated in duplicate onto the four culture media using the surface and deep plating methods. Plates were incubated at $45^{\circ} \mathrm{C}$ for 72 hours. The remaining juice with spores was incubated for 24 hours for germination. Growth analysis after enrichment in the reconstituted juice was repeated after 24 hours. Colonies were fixed with Gram and spore staining (Wirtz-Conklin staining technique) in order to verify the morpho-staining characteristics under optical microscopy.

\section{Statistical analysis}

The three independent assays were conducted in duplicate. The results of the microbiological count mean were examined with the analysis of variance (ANOVA), and significant differences were confirmed by the Tukey's post hoc test with $\alpha=0.05$. 


\section{RESULTS}

An initial population of $6 \log \mathrm{CFU} / \mathrm{mL}$ of each micro-organism was inoculated on the different media to verify recovery. Figure 1 shows the recovery results of reference strains and pasteurized orange juice isolates in the different culture media.

Although the germination results found for the medium of $\mathrm{K}$ agar were lower than the other media, no significant differences were found in the assays performed with CBMAI 0244 $4^{\mathrm{T}}$, CBMAI 0281 and CBMAI 0294. Significantly lower values with $\mathrm{K}$ agar medium, however, were observed in the recovery of CBMAI $0298^{\mathrm{T}}$ and CBMAI 0278.

Plate monitoring showed substantial growth of the colonies in the ALI, BAT and YSG media after the third day of incubation in all of the assays. While no colony growth occurred in $\mathrm{K}$ agar medium until the third day of incubation, counts lower than the other culture media were observed after the fifth day of incubation. The different composition of $\mathrm{K}$ agar may not have favored the fast development of Alicyclobacillus cells.

An initial spore population of $2 \log \mathrm{CFU} / \mathrm{mL}$ was used for inoculation in reconstituted orange juice. Recovery of about $2 \log \mathrm{CFU} / \mathrm{mL}$ was achieved after thermal shock, plating and incubation at $45^{\circ} \mathrm{C}$. The recovery of $2 \log \mathrm{CFU} / \mathrm{mL}$ was observed after juice incubation with the inoculum for 24 hours at $45^{\circ} \mathrm{C}$. Figures 2 and 3 display the recovery results of the inoculation with Alicyclobacillus acidoterrestris spores enriched in reconstituted orange juice with the surface and deep plating methods, respectively, at 0 and 24 hours.

No significant differences in colony counts of the different culture media for assays at 0 hour were found. Similarly, no significant differences between surface and deep plating were observed at this time. There were no significant differences between the four media and between plating methods in the assays performed at 24 hours. However, $\mathrm{K}$ agar medium

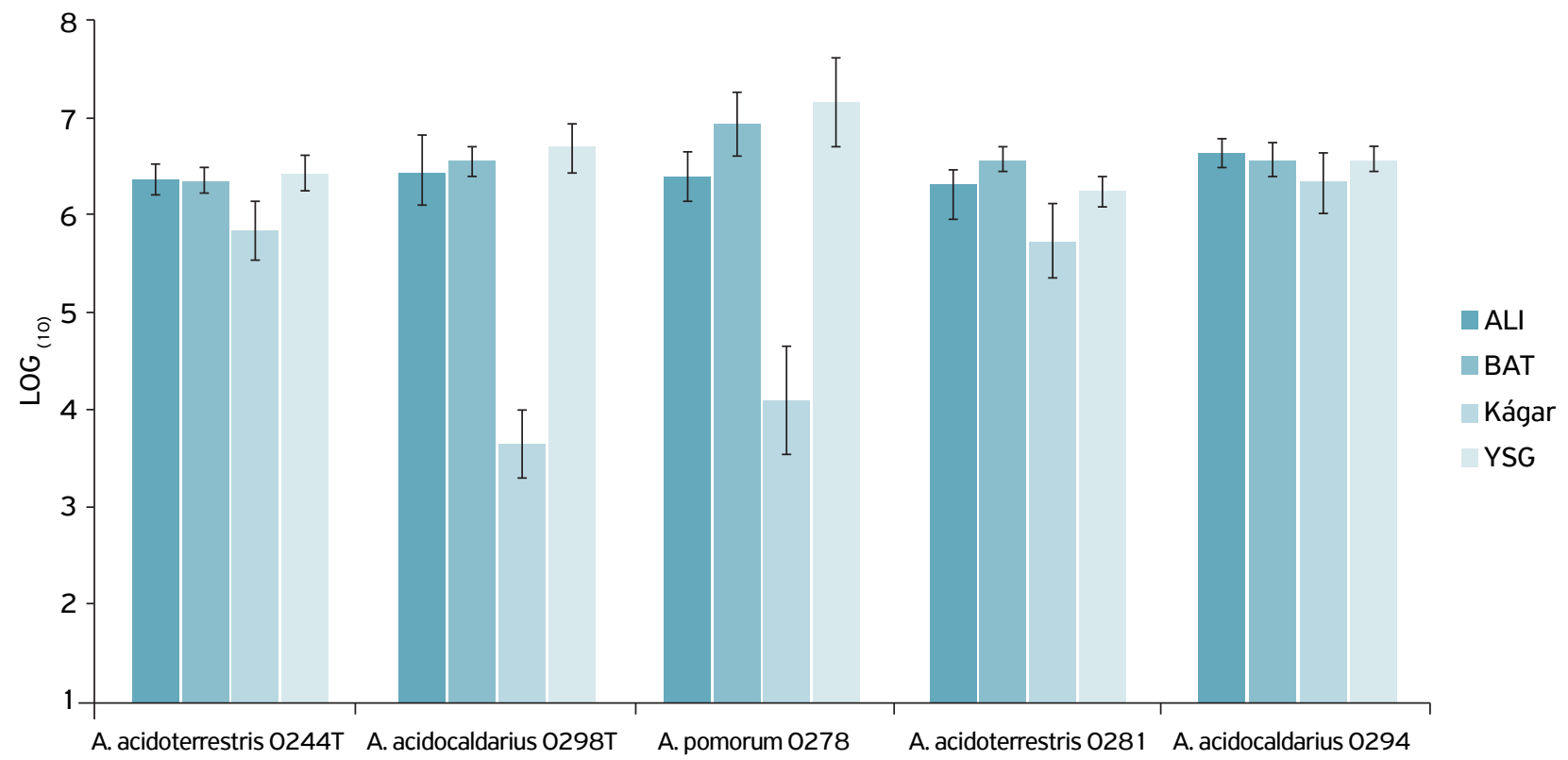

Figure 1. Recovery results of reference strains and pasteurized orange juice isolates ( $\log \mathrm{CFU} / \mathrm{mL}$ ).

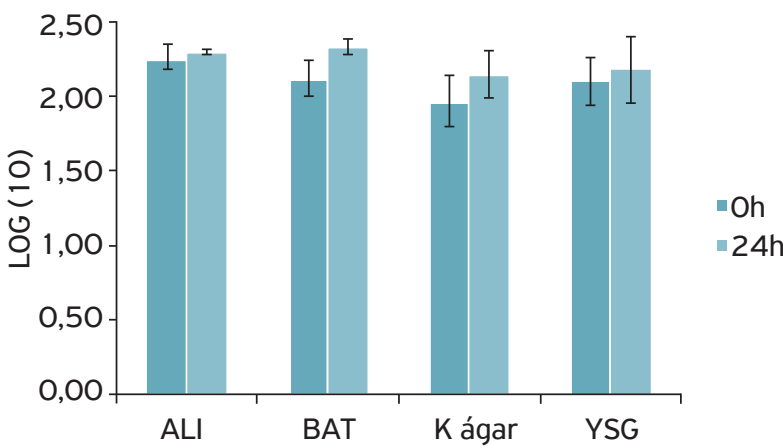

Figure 2. Results of Alicyclobacillus acidoterrestris growth with enrichment in reconstituted orange juice plated with the surface method at Oh and 24 hours (log CFU/mL).

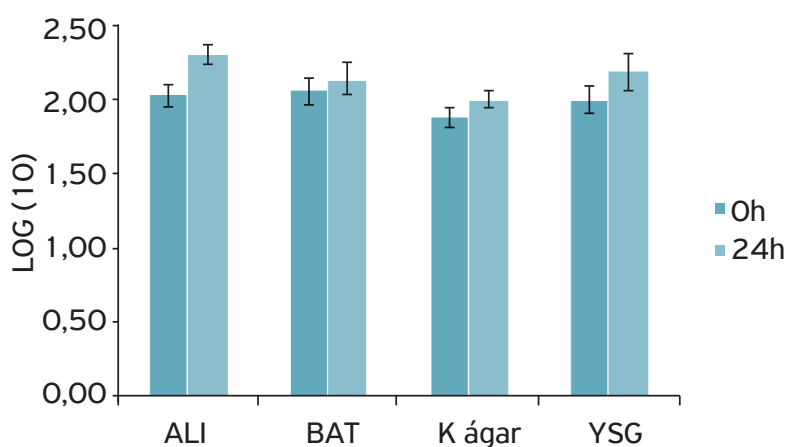

Figure 3. Results of Alicyclobacillus acidoterrestris growth with enrichment in reconstituted orange juice plated with the deep method at $\mathrm{O}$ and 24 hours ( $\log \mathrm{CFU} / \mathrm{mL}$ ). 
demonstrated an overall poorer performance in the recovery of colonies at both times.

Figure 4 shows the morphological characteristics of colonies after 72 hours of incubation at $45^{\circ} \mathrm{C}$. The characteristics of colonies in ALI, BAT and YSG media were similar, for example, circular and opaque with regular light-cream edges. YSG also revealed some translucent colonies. $\mathrm{K}$ agar, on the other hand, presented different morphological characteristics from the other culture media with irregular edges and some translucent colonies.

Gram-positive and spore staining confirmed the morpho-staining characteristics of the Alicyclobacillus colonies that grew in the four culture media. Gram-positive bacilli with sub-terminal spores, characterizing inoculated colonies, were observed.

\section{DISCUSSION}

Results from the four tested media demonstrated good recovery of micro-organisms, both with direct inoculation and with the enrichment in reconstituted orange juice. Kagar results, however, were lower than the other media in the two performed assays.

According to the methodology described by WISSE; PARISH (1998), $\mathrm{pH}$ should be adjusted to 3.5 in the preparation of ALI medium. Nonetheless, the standard $\mathrm{pH}$ at 4.0 used in this study did not affect the results negatively. When compared to BAT medium, in which, according to DeInhard et al. (1987), $\mathrm{pH}$ should be adjusted to 4.0, the results obtained with ALI medium were satisfactory. In a previous study, PARISH; Goodrich (2005) reported that ALI medium recovered a significantly larger number of Alicyclobacillus in relation to $\mathrm{K}$ agar medium, which was corroborated by the current study.

According to the International Federation of Fruit Juice Producers (IFu, 2007), when $\mathrm{K}$ agar medium was incubated at $45^{\circ} \mathrm{C}$, the growth of several species of alicyclobacillus was constrained, and only the growth of $A$. acidoterrestris was observed. The American Public Health Association (APHA), however, recommends $\mathrm{K}$ agar medium at $\mathrm{pH} 3.7$ and 3-day incubation at $43^{\circ} \mathrm{C}$.
When Wittrumn (2007) evaluated the effect of Potato Dextrose Agar (PDA), Orange Serum Agar (OSA), Bacillus acidocaldarius medium (BAM), YSG and K agar media upon the growth of alicyclobacillus, the author reported that PDA and OSA media provided the best cell recovery. $\mathrm{K}$ agar, on the other hand, failed to recover $A$. acidoterrestris cells inoculated in concentrated pear juice, and failed to recover $A$. pomorum cells inoculated after $80^{\circ} \mathrm{C}$ thermal treatment for 10 minutes.

According to Murray et al. (2007), the comparison of several culture media revealed that BAT medium tended to provide the best results, supporting the IFU's suggestion to use BAT medium to detect Alicyclobacillus in fruit juices. The current analysis is in agreement with these results, although ALI and YSG media presented results comparable to BAT.

With regard to the isolation and counting methods of spore recovery, there were no significant differences between surface and deep plating. Studies by Pettipher et al. (1997) and Murray et al. (2007), however, showed that the surface method provided better results when compared to the deep method. Colonies sown deep in the medium are frequently overlain by others, and are smaller than colonies inoculated on the surface, making colony counting difficult. The characteristics of colonies and the recovery of isolates for identification proved to be easier with the surface method. This was also probably due to the physiological characteristics of the micro-organisms.

The results in current analysis indicated a significant difference concerning the growth of $A$. acidocaldarius in $\mathrm{K}$ agar medium in comparison to the other media. This is corroborated by the results of MurRAY et al. (2007), who compared the recovery of $A$. acidocaldarius inoculated in K agar, BAT and ALI media, and found that the recovery of the bacteria in $\mathrm{K}$ agar medium was significantly lower. FARRAND et al. (1983) showed that incubation temperatures superior to $43^{\circ} \mathrm{C}$ favored the growth of $A$. acidocaldarius. In their study, the temperature was $45^{\circ} \mathrm{C}$, and the recovery of $A$. acidocaldarius was higher compared to $A$. acidoterrestris not only with relation to the inoculation of reference strains, but also in the recovery of pasteurized orange juice isolates. This result suggests that temperatures higher than $45^{\circ} \mathrm{C}$ are not required for the development of $A$. acidocaldarius.

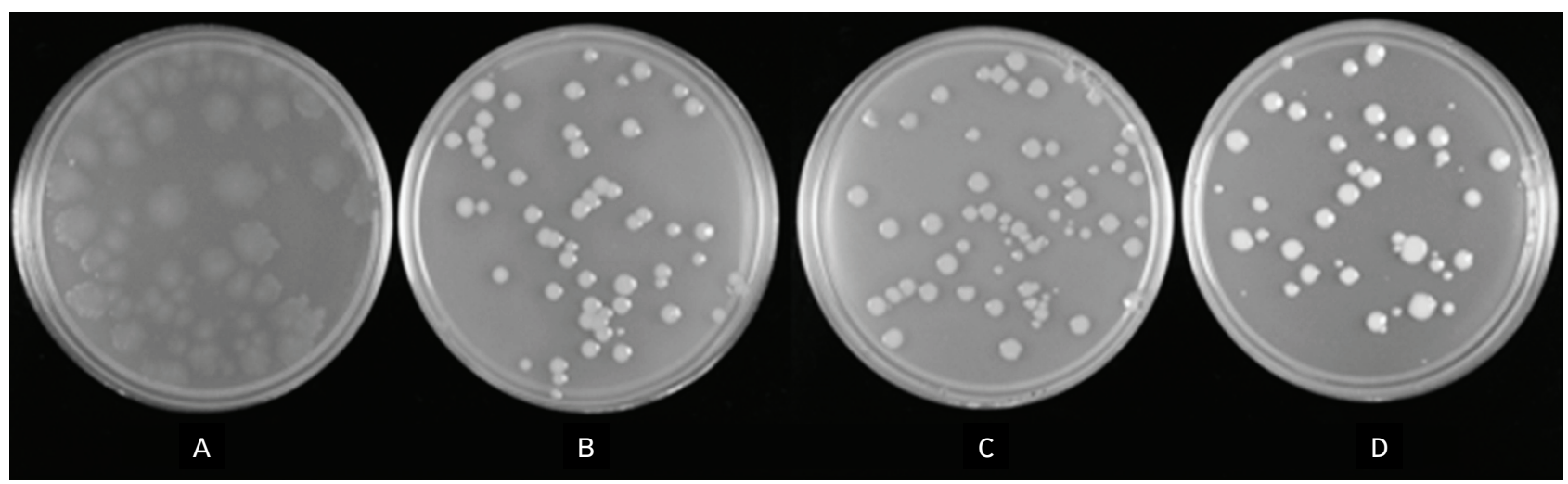

Figure 4. Alicyclobacillus acidoterrestris colonies in: (A) K agar, (B) ALI, (C) YSG and (D) BAT agar after 72 hours at $45^{\circ} \mathrm{C}$. 
Abreu Filho (2005) characterized the taxonomy of thirty inocula of Alicyclobacilli isolates from orange juice processing, with special attention given to the inocula CBMAI 0278, CBMAI 0281 and CBMAI 0294 used in the current study. CBMAI 0278, characterized as A. pomorum-like, did not show any changes in smell, and no cell recovery was obtained after inoculation in reconstituted orange juice in the assays conducted by the author. This showed that the species had no spoilage potential for reconstituted orange juices, even though it provided excellent cell recovery by the direct inoculation in ALI, BAT and YSG media. that ALI, BAT and YSG media recovered the initial population of the different tested inocula with no significant differences between them. The easy preparation of ALI and YSG media is an advantage when compared to the preparation of BAT. $\mathrm{K}$ agar medium provided the lowest recovery for all of the tested inocula with significant differences in the recovery of A. acidocaldarius CMAI $0298^{\mathrm{T}}$ and A. pomorum-like CBMAI 0278. K agar medium at $\mathrm{pH} 4.0$ was not ideal for the recovery of alicyclobacilli enriched in orange juice incubated at $45^{\circ} \mathrm{C}$.

\section{ACKNOWLEDGEMENTS}

\section{CONCLUSIONS}

The evaluation of different culture media and enrichment in orange juice upon the growth of Alicyclobacillus spp. showed
The authors would like to thank Universidade Estadual de Maringá, Brazil, the Coordination for the Improvement of Higher Education Personnel (CAPES) and Fundação Araucária for funding the study.

| | | | | | | | | | | | | | | | | | | | | | | | | | | | | | | | | | | | | | | | | | | | | | | | | | | | | | | | | | | | | | | | | | | | | | | | | | | | | | | | | | | | | | | | | | | | | | | | | | | | | | | | | | | | | | | | | | | | | | | | | | | | | | | | | | | | | | | | | | | | | | | | | | | | | | | | | | | | | | | | | | | | | | | | | | | | | | | | | | | | | | | | | | | | | | | | | | | | | | | | | | | | | | |

\section{REFERENCES}

ABREU FILHO, B.A. Caracterização taxonômica de linhagens de Alicyclobacillus spp. isolados na indústria de suco concentrado de Iaranja. 2005. Tese (Doutorado). Faculdade de Engenharia de Alimentos, Universidade Estadual de Campinas, Campinas. 2005.

BR CITRUS. Exportações brasileiras do comércio citrícola. Disponível em: http://www.citrusbr.com.br/exportadores-citricos/estatisticas. Acesso em: 16 abr. 2012.

DEINHARD, G.; SAAR, J.; KRISCHKE, W.; PORALLA, K. Bacillus cycloheptanicus sp. nov.a new thermoacidophile containing $\varpi^{-}$ cycloheptane fatty acids. Systematic and Applied Microbiology, v.10, p.68-73, 1987.

FARRAND, S.G.; LINTON, J.D.; STEPHRNSON, R.J.; MACCARTHY, W.V. The use of response surface analysis to study growth of Bacillus acidocaldarius throughout the growth range of temperature and $\mathrm{pH}$. Microbiology, v.135, n.4, p.135: 272, 1983.

GOCMEN, D.; ELSTON, A.; WILLIANS, T.; PARISH, M.; ROUSEFF, R.L. Identification of medicinal off-flavours generated by Alicyclobacillus species in orange juice using GC-olfactometry and GC-MS. Letters in Applied Microbiology, v.40, p.172-177, 2005.

HIPPECHEN, B.; ROLL, A.; PORALLA, K. Occurrence in soil of thermoacidophilic bacilli possessing $\varpi$-cyclohexane fatty acids and hopanoids. Archives of Microbiology, v.129, p.53-55, 1981.

International Federation of Fruit Juice Producers - IFU. Method on the detection of taint producing Alicyclobacillus in fruit juices. IFU Method n. 12; Paris: 1-11. 2007.

MOTOHIRO, N.; HIROKO, S. Selective culture medium for detecting thermotolerant acid-fast Bacillus and its detection. Japan Patent: 06-283459. 1994.
MURRAY, M.B.; JOSHUA, B.G.; JEE-HOON, R.; HARRISON, M.A.; BEUCHAT, L.R. Evaluation of direct plating methods to enumerate Alicyclobacillus in beverages. International Journal of Food Microbiology, v.115, p.59-69, 2007.

PARISH, M.E.; GOODRICH, R.M. Recovery of presumptive Alicyclobacillusstrains from orange fruit surfaces. Journal of Food Protection, v.68, p.2196-2200, 2005.

PETTIPHER, G.L.; OSMUNDSON, M.E.; MURPHY, J.M. Methods for the detection and numeration of Alicyclobacillus acidoterrestris and investigation of growth and production of taint in fruit juice and fruit juice containing drinks. Letters in Applied Microbiology, v.24, p.185-189, 1997.

PONTIUS, A.; RUSHING, J.; FOEGEDING, P.M. Heat resistance of Alicyclobacillus acidoterrestris spores as affected by various $\mathrm{pH}$ values and organic acids. Journal of Food Protecion, v.61, p.41-46, 1998.

SILVA, F.V.M.; GIBBS, P. Alicyclobacillus acidoterrestris spores in fruit products and design of pasteurization processes. Food Scence and Technology, v.12, p.68-74, 2001.

WALLS, I.; CHUYATE, R. Isolation of Alicyclobacillus acidoterrestris from fruit juices. Journal of AOAC International, v.83, p. 1115 $1120,2000$.

WISSE, C.A.; PARISH, M.E. Isolation and enumeration of spore forming thermoacidophilic, rod-shaped bacteria from citrus processing environments. Dairy Food and Environmental Sanitation, v. 18 , p.504-509, 1998.

WITTHUHN, R.C.; DUVENAGE, W.; GOUWS, P.A. Evaluation of different growth media for the recovery of the species of Alicyclobacillus. Letters in Applied Microbiology. v.45, p.224-229, 2007. 